\title{
MENINGITES BACTERIANAS RECIDIVANTES
}

\author{
MARIA VALERIANA L. MOURA-RIBEIRO * - WILMA TEREZINHA ANSELMO-LIMA ** \\ JOSE ANTONIO A. DE OLIVEIRA **
}

\begin{abstract}
RESUMO - $O$ estudo das fístulas liquóricas, envolvendo anormalidades otorrinolaringológicas, deve se basear na procura da causa fundamental que leva às meningites recidivantes. As malformaçóes congênitas, as anormalidades pós-traumáticas e pós-operatórias ou, ainda, associadas a doenças que envolvem ossos cranianos, constituem as causas básicas a serem pesquisadas. Os traumas cranianos podem resultar em fístula liquórica com possibilidade de meningites bacterianas de repetịão.
\end{abstract} diano.

PALAVRAS CHAVE: meningite bacteriana recidivante, fístulas, liquido cefalorraqui-

\section{Recurrent bacterial meningitis.}

SUMMARY - The study of CSF fistulae, and especially those involving otolaryngological anomalies, must be based on the search for the causative problem of recurrent meningitis. Congenital malformations, post-traumatic and post-operative situations or even diseases involving the cranial bones are basic causes that should be studied. Currently, cranial trauma is the most usual cause of CSF fistulae, with the possibility of recurrent bacterial meningitis.

KEY WORDS: recurrent bacterial meningites, fistulae, cerebrospinal fluid.

Dentro do estudo das fístulas liquóricas envolvendo anormalidades otorrinolaringológicas, o liquido cefalorraquidiano (LCR) pode ser detectado no ouvido médio e pode ser eliminado pelas narinas com a secreção nasal, devido a vários fatores. Constituem, entretanto, eventos raramente registrados na literatura 4,6,8.

Um dos locais de resistência diminuída, na dura máter, pode ser a região da lâmina crivosa do osso etmóide e, também, o meato auditivo interno. Dessa forma, infecções repetidas e superpostas podem ocorrer em defeitos da dura máter ou do osso adjacente ao defeito dural, ambos levando a comunicação direta ou fístula entre o espaço subaracnóideo e o exterior. No estudo das causas básicas de fístulas liquóricas com exteriorização, sinalizamos as malformações congênitas, as situações póstraumáticas e pós-operatórias, bem como as associadas a doenças envolvendo ossos cranianos.

$\mathrm{Na}$ classificação das fístulas liquóricas otológicas, podem ser consideradas: as extra-labirinticas com defeito no assoalho da fossa craniana média, na região do tegmen timpânico; e as intra-labirínticas, em que a comunicação do ouvido médio e espaço subaracnóideo se faz por estruturas do ouvido interno, aparecendo na fossa craniana posterior. É importante remarcar que as fístulas podem ser: abertas, quando há passagem do LCR para o meato auditivo externo, através da perfuração da membrana timpânica; ou fechadas, em que o LCR passa, via tuba, para o nasofaringe

Faculdade de Medicina de Ribeirão Preto, Universidade de São Paulo (USP): * Departamento de Neuropsiquiatria e Psicologia Médica; ** Departamento de Oftalmologia e Otorrinolaringologia.

Dra. Wilma Terezinha Anselmo-Lima - Departamento de Oftalmologia e Otorrinolaringologia Faculdade de Medicina de Ribeirão Preto, USP - Av. Bandeirantes 3900 - 14049 Ribeirão Preto SP - Brasil. 
estando, portanto, a membrana timpânica integra e a rinoliquorréia sugerindo fistulização da cavidade nasal ou fossa craniana anterior. Menos frequentemente a rinoliquorréia não se torna aparente, podendo haver drenagem direta para o rinofaringe 3 .

Uma vez levantada a hipótese de fístula liquórica otológica, o interesse maior constitui a detecção da causa fundamental. Nesse particular, as malformações congênitas devem ser objeto primordial de investigação. Assim, na sindrome de surdez congênita, primeiramente descrita por Nenzelius em 1951, meningites recidivantes apresentam-se com fluxo de LCR sem reconhecimento exato da fístula 5 . Os locais mais comuns de deiscência entre o espaço subaracnóideo, ouvido interno e médio são o tegmen timpânico, as células mastóideas, o aqueduto coclear $\mathrm{e} o$ conduto auditivo interno (Fig. 1). É sabido que, no recém-nascido normal, o aqueduto coclear é largo, aberto e curto; em havendo malformação labiríntica, este permanece aberto como um cisto largo, comunicante com o espaço subaracnóideo. Tem sido demonstrado radiologicamente que o LCR passa para o conduto auditivo interno via feixes perineurais do VII e VIII nervos; como a parte externa do meato auditivo interno é próxima ao vestíbulo, forma-se então uma conexão entre o espaço subaracnóideo e o labirinto cístico. Entretanto, objetivamente, nesses casos o meato interno é muito estreito.

$\mathrm{Na}$ surdez congênita, são conhecidos os defeitos provenientes de anormalidades do desenvolvimento fetal como, também, do período neonatal. Há, por exemplo, a aplasia do Mondini, descrita há cerca de 200 anos, em que a espira basal da cóclea não se desenvolve e as espiras média e apical formam vesícula única. Também pode ocorrer subdesenvolvimento similar das estruturas vestibulares. Em alguns casos pode faltar o labirinto membranoso, utrículo e canais semicirculares, janela oval ou mesmo a platina do estribo; às vezes se constatam restos de epitélio sensorial, sugerindo alguma funcionalidade. A possibilidade diagnóstica pode ser levantada a partir da otorréia ou rinorréia liquórica, disacusias neuro-sensoriais ou mistas, e meningites recidivantes. Dessa maneira, se impõem a investigação radiológica, contrastada ou não, a injeção transtimpânica de soro albumina humana com moléculas marcadas 6,8.

Em relação aos traumas otológicos, as fraturas na base do crânio envolvendo o osso temporal, com abertura da dura máter, constituem a causa mais frequente de fístula liquórica com possibilidade de meningites de repetição 3 . As grandes fraturas, tanto do tipo longitudinal como transversal, podem romper as meninges e provocar escoamento do LCR pelo meato auditivo externo. O tempo decorrido, do acidente à

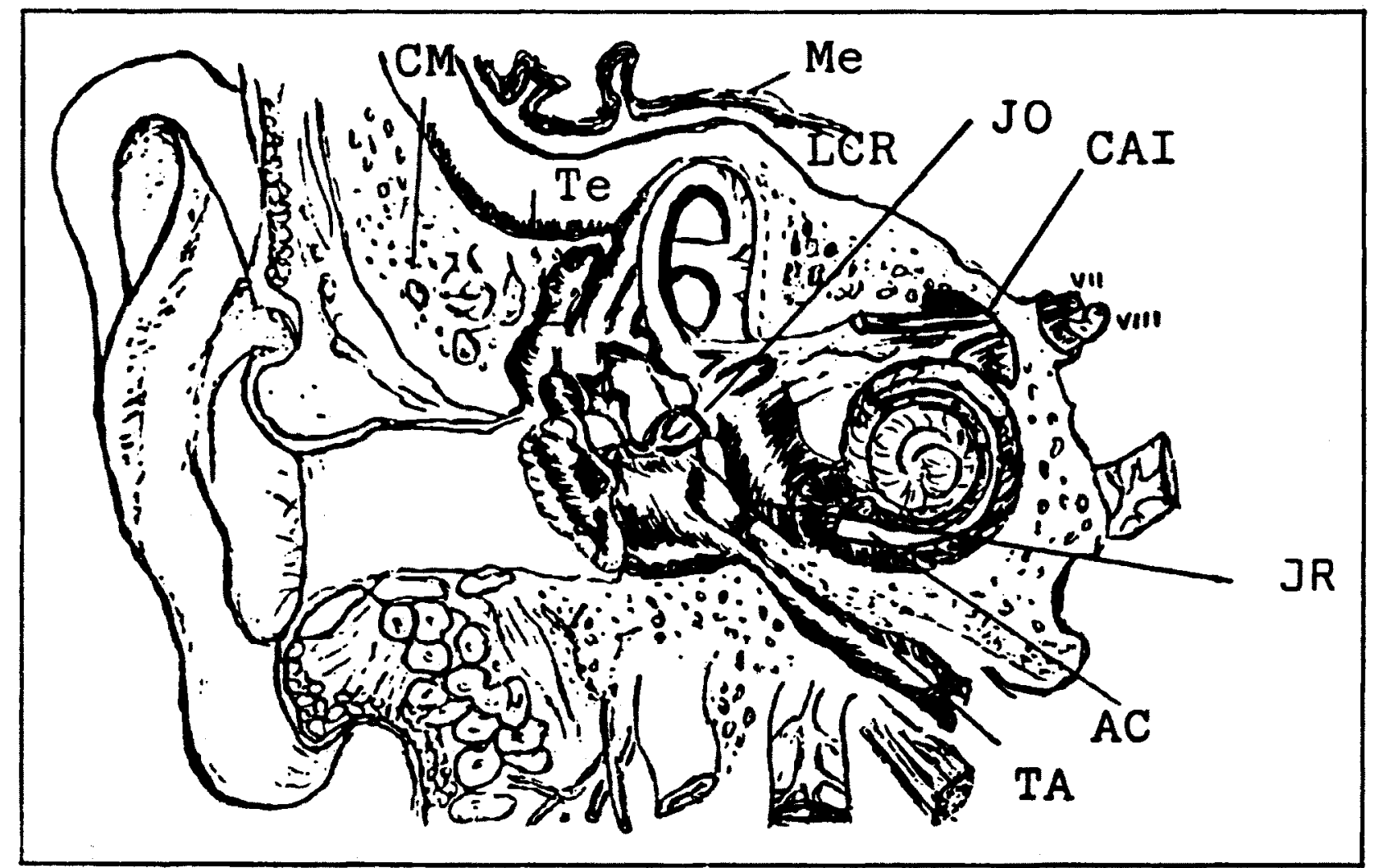

Fig. 1. Esquema frontal do ouvido direito no homem: possibilidades de fistulas liquoricas.

Te, tegmen; $C M$, celulas mastoideas; $C A I$, conduto auditivo interno; $A C$, aqueduto coclear; Me, meninges; JO, janela oval; JR, janela redonda; TA, tuba auditiva. 
infecção meníngea, pode variar de dias a anos. As brechas no osso endocondral podem formar trajetos fistulosos permanentes com o vestíbulo, condutos semicirculares e cóclea. As capas endocondral e endóstica da cápsula óptica são notórias por sua tendência e reparação lenta e incompleta, mesmo que a capa perióstica externa possa se curar prontamente e por completo. Estudos anatômicos das fraturas do osso somente evidenciaram fibrose nas linhas de fratura nos sítios em que a cobertura periósticá era insuficiente. A regeneração cicatricial se faz por simples calo fibroso, pode ser deiscente e servir, portanto, de entrada para infecções intracranianas, anos depois.

As fístulas liquóricas nasais, de forma semelhante às otológicas, podem surgir após trauma acidental ou iatrogênico; a área comum de fratura compromete principalmente o seio frontal, esfenoidal, etmoidal ou lâmina crivosa. As fístulas nasais não traumáticas, podem se apresentar em pacientes com: pressão liquórica elevada, particularmente nas hidrocefalias, nos casos de tumores intracranianos; ou pressão normal, como nos casos de erosão osteolítica e anomalia congênita. Os defeitos congênitos da lâmina crivosa do etmóide podem ser causa importante de rinorréia e consequentes episódios repetidos de meningites. Como métodos diagnósticos para detectar a fístula, incluem-se a observação direta e dinâmica da rinorréia, a determinação do nível de glicose na secreção nasal, o teste do índigo carmino e o estudo dinâmico com injeção intratecal de albumina marcada 2.

O trajeto fistuloso dermóide infectado constitui, também, anormalidade facilitadora de meningites bacterianas e paralisia dos membros inferiores de instalação súbita. Portanto o diagnóstico precoce, antes que se instale a infecção, permite o tratamento profilático com resultados favoráveis; dessa forma é importante o exame clínico cuidadoso das anomalias de linha média (pertuitos, tufos de pelos, hemangiomas planos) particularmente nas regiões occípito-cervical e lombo-sacra 1.

Menos frequentemente a contaminação do LCR está ligada à introdução acidental de microrganismo durante mielografia ou pneumencefalografia ?.

Lembramos ainda as meningites cisticercóticas repetidas, que podem ou não ser acompanhadas de manifestações encefalíticas conjuntamente.

A partir das alterações expostas, ao exame clínico cuidadoso, se impõe avaliação otorrinolaringológica ampla, procurando detectar o defeito estrutural básico determinante das meningites recidivantes.

\section{REFERENCIAS}

1. Almeida GM, França LCM, Araújo MMP. Trajeto fistuloso dermóide congênito infectado. Pediat Prat 1968, 39:35-38.

2. Hand WL, Sanford JP. Postraumatic bacterial meningitis. Ann Inter Med 1970, 72:869874.

3. Jones HM. The problem of recurrent meningitis. Proc Roy Soc Med 1974, 67:1141-1147.

4. Anselmo WT, Oliveira JAA, Moura-Ribeiro MVL. Meningites bacterianas recidivantes em otorrinolaringologia. Rev Bras Otorrinolaringol 1989, 55:22-30.

5. Nenzelius C. On spontaneous cerebrospinal otcrrhea due to congenital malformations. Acta Otolaryngol 1951, 39:314-328.

6. Rice WJ, Waggoner LG. Congenital cerebrospinal fluid otorrhea via a defect in the stapes footplate. Laryncoscope 1967, 77:341-349.

7. Rose HD. Pneumococcal meningitis following intratecal infections. Arch Neurol 1966, 14:597-600.

8. Schultz P, Stool $S$. Recurrent meningitis due to a congenital fistula through the stapes footplate. Am J Dis Child 1970, 120:553-554. 